\title{
Okul Müdürlerinin Aday Öğretmenlere Rehberlik Etmeleri ile Liderlik Oryantasyonları Arasındaki İlişki
}

\author{
Mehmet Fatih KARACABEY*
}

\begin{abstract}
Öz: Bu araştırmada okul müdürlerinin okullarında görev yapan aday öğretmenlere rehberlik edebilme düzeyiyle liderlik oryantasyonları arasındaki ilişki incelenmektedir. Çalışmada tarama modeliyle Şanlıurfa' da görev yapan 307 aday öğretmenden toplanan veriler analiz edilmiştir. Araştırmanın sonucunda okul müdürlerinin okullarında görev yapan aday öğretmenlere rehberlik edebilme ve liderlik oryantasyonlarının orta düzeyde olduğu ve rehberlik edebilme düzeyleriyle liderlik oryantasyonları arasında yüksek düzeyde ilişki bulunduğu belirlenmiştir. İlkokul ve lise müdürlerinin ortaokul müdürlerine göre aday öğretmenlere eğitim-öğretim alt boyutunda daha iyi rehberlik ettiği saptanmıştır. Ayrıca okul müdürlerinin sınıf öğretmenliği mezunu aday öğretmenlere branş öğretmenliği mezunu aday öğretmenlerden daha iyi rehberlik ettiği ve liderlik oryantasyonlarının cinsiyet, okul türü, branş ve görev yerine göre farklılık göstermediği belirlenmiştir.
\end{abstract}

Anahtar Sözcükler: Aday Öğretmen, Rehberlik, Liderlik, İlişki, Şanlıurfa.

\section{The Relationship Between School Principals' Guidance of Prospective Teachers and Leadership Orientation}

\begin{abstract}
In this study, which investigates the relationship between school principals' level of being able to guide prospective teachers in their schools and leadership orientations, data collected from 307 candidate teachers working in Şanlıurfa were analyzed. As a result of the study, it was found that school principals' guidance and leadership orientations were at a moderate level, there is a high level of relationship between the level of guidance and leadership orientation, primary and high school principals provide better guidance to prospective teachers in the sub-dimension of education-teaching, school principals have better guidance to prospective teachers who have graduated from primary school teachers than prospective teachers with branch education and it was determined that leadership orientations did not differ according to gender, type of school, branch and task location.
\end{abstract}

Keywords: Prospective Teacher, Guidance, Leadership, Relationship, Şanlıurfa. 
Toplumlar ancak öğretmenlerinin seviyelerine kadar yükselebilirler. Öğretmenler ne kadar nitelikli olurlarsa, toplumlar da o kadar ilerleyebilir. Bunun için öğretmenlerin nitelikli eğitimi çok önemlidir. Çünkü öğretmenlerin seviyeleri aldıkları eğitime bağlıdır. Ancak eğitim sayesinde öğretmenler mesleklerinde verimli olabilir ve daha az sorun yaşarlar. Fakat ne kadar iyi bir hizmet öncesi eğitim alınırsa alınsın, yeni atanan öğretmenler birçok sorunla karşılaşmaktadırlar (Akdağ, 2014; Erdemir, 2007; Feiman-Nemser, 2003; Hammond, 2005; Korkmaz, Saban ve Akbaşlı, 2004; Sarı ve Altun, 2015). Bu sorunlar öğretimi planlama ve uygulama, sınıf yönetimi, toplum ile ilişkiler, fiziksel çevreye uyum, okulun fiziki altyapı eksiklikleri, meslektaş, yönetici, veli ve rehber öğretmenle ilişkilerinden kaynaklanabilmektedir (Kozikoğlu ve Senemoğlu, 2018). Bu sorunlardan dolayı dünya genelinde mesleğe yeni başlayan öğretmenlerin ilk birkaç yılda mesleklerini bıraktıkları belirtilmektedir (Smith ve Ingersoll, 2004). Bu nedenle yeni öğretmenler ilk yıllarında eğitime ihtiyaç duyarlar (Wong ve Tsu, 2007). Türkiye' de aday öğretmenlere sağlanan eğitimin olumlu (Arslan ve Özpınar, 2008; Balkar ve Şahin, 2014; Gül, Türkmen ve Aksel, 2017; Köse, 2016; Yirci ve Kocabaş, 2010) ve olumsuz (Duran, Sezgin ve Çoban, 2011; Ekinci, 2010; Özonay, 2004;) yanları bulunmaktadır. Mesleğe yeni atanan öğretmenlerin adaylık süresince aldıkları eğitimler ise sürekli olarak değişik düzenlemelere tabi olmuştur.

Öğretmenlerin adaylık eğitimi ilk defa 1930 tarihli ve 1532 Sayılı İlk ve Orta Tedrisat Muallimlerinin Terfi ve Tecziyeleri Hakkında Kanun ile düzenlenmiştir. Bu kanunla öğretmenlere bir yıllık staj süresi sonunda eğitim kabiliyeti, sicili ve teftiş raporuna göre öğretmen unvanı verilmiştir (İlk ve Orta Tedrisat, 1930). 1943 tarihli 5308 sayılı Hususi İdarelerden Maaş Alan İlkokul Öğretmenlerinin Kadrolarına, Terfi, Taltif ve Cezalandırılmalarına ve Bu Öğretmenler İçin Teşkil Edilecek Sağlık ve İçtimai Yardım Sandığı ile Yapı Sandığına ve Öğretmenlerin Alacaklarına Dair Kanun ile ilkokul öğretmenliğine atananların bir yıldan üç yıla kadar stajyer olarak çalışmaları ve sonunda üç kişilik bir kurulun kararıyla asil öğretmen olmaları esas alınmıştır (Hususi İdarelerden Maaş Alan, 1943). 1965 tarihli, 657 sayılı Devlet Memurları Kanunu, adaylık sürecini yeniden düzenlemiştir (Devlet Memurları Kanunu, 1965). Bu kanuna dayalı olarak, 1985 tarihinde çıkarılan Milli Eğitim Gençlik ve Spor Bakanlığına Bağlı Okul ve Kurumlara Stajyer Olarak Atanan Öğretmenlerin Stajyerlik İşlemlerine İlişkin Yönerge ile aday öğretmenlerin ilk olarak yetiştirme programının uygulandığı okullarda bir ila iki yıl boyunca okul müdürü ve rehber öğretmenin sorumluluğunda yetiştirildikten sonra başarılı olmaları halinde asıl görev yerlerine atanmaları istenmiştir (Milli Eğitim Gençlik ve Spor Bakanlığına Bağlı Okul ve Kurumlara Stajyer Olarak Atanan Öğretmenlerin Stajyerlik İşlemlerine İlişkin Yönerge, 1985). 1995 tarihli Millî Eğitim Bakanlığı Aday Memurların Yetiştirilmelerine İlişkin Yönetmelikte adaylık eğitimi temel eğitim, hazırlayıcı eğitim ve uygulamalı eğitim olarak üç sürece ayrılmıştır (Millî Eğitim Bakanlığı Aday Memurların Yetiştirilmelerine İlişkin Yönetmelik, 1995). Fakat bu süreçler öğretmenlerin asıl ihtiyaç duydukları mesleğe ilişkin eğitimlerden çok genel memurluğa ilişkin eğitimleri içerdiğinden etkili olamamışlardır (Balkar ve Şahin, 2014; Özonay, 2004). 2015 tarihinde yayımlanan Öğretmen Atama ve Yer Değiştirme Yönetmeliği, aday öğretmenlik sürecini yeniden değiştirmiştir. Yeni atanan öğretmenlerin bir yıl boyunca adaylık sürecinden geçmeleri ve bu sürede üç performans değerlendirmesi sonunda girilen yazılı sınavdan başarılı olmaları halinde kadroya alınmaları esastır. Bu uygulama Ağustos 2015 atama dönemiyle birlikte başlamıştır (Öğretmen Atama ve Yer Değiştirme Yönetmeliği, 2015). Mart 2016 tarihinde Aday Öğretmen Yetiştirme Sürecine Dair Yönerge yayımlanmıştır. Bu yönergede aday öğretmenlik sürecinin ilk altı ayı, sınıf-okul içi ve dışı faaliyetler ile hizmet içi eğitim seminerlerinden oluşan işe başlama eğitiminden oluşur. Aday öğretmenler kendi seçtikleri bir ilde bu eğitimi alabilmekteydiler (Aday Öğretmen Yetiştirme Sürecine Dair Yönerge, 2016). Aday öğretmenlerce olumlu bulunan bu uygulamanın (Topsakal ve Duysak, 2017) bazı olumsuzluklara neden olabileceği belirtilmiştir (Kozikoğlu ve Çökük, 2017; Köse, 2016). Daha sonra yapılan bir değişiklikle öğretmenlerin atandıkları kurumda eğitim almaları kararlaştırılmıştır. Bu yaklaşım ise olumlu karşılanmıştır (Sarikaya, Samancı ve Yılar, 2017). Bunun nedeni olarak, okul müdürlerinin aday öğretmenlerin eğitiminde önemli bir rol oynamaları öne sürülebilir. Yapılan tüm bu değişikliklerde de okul müdürünün rehberlik rolü korunmuş ve giderek daha da önemli hale gelmiştir. Müdürlerin aday öğretmenlere etkili bir şekilde rehberlik edebilmeleri için yöneticilikten çok liderliğe başvurmaları gerekebilir. Dolayısıyla bu noktada müdürlerin sahip oldukları liderlik oryantasyonlarının önemi ortaya çıkmaktadır. 
Bolman ve Deal (2017) örgütleri yapısal, insan kaynakları, politik ve sembolik olmak üzere dört boyutta ele almışlardır. Liderlerin her bir yapıya göre sergiledikleri tutum ve davranışlar onların oryantasyonlarını belirlemektedir. Yapısal boyut, örgütleri birer fabrika veya makine olarak görür. Sistem yaklaşımıyla uyumlu olan bu boyutta, hedeflere göre kurallı bir örgütlenme söz konusudur. Bürokrasinin de gereği olan iş bölümü ve uzmanlaşmayla verimlilik amaçlanır. Rasyonel karar ve davranışlara öncelik verilir. Yapı duruma uymadığında sorunlar ortaya çıkabilir. Yapısal oryantasyona sahip liderler, sorunları yapıda değişikliğe giderek çözerler. İnsan kaynakları boyutu ise örgütü bir aile olarak görür. Bu boyutta esas olan örgütteki insanların ihtiyaçlarının karşılanmasıdır. Örgütün çalışanlarının ihtiyaçlarını karşılayabildiği ölçüde verimli olabileceği vurgulanır. İnsan kaynakları oryantasyonundaki liderler insanlar hakkında kendini gerçekleştiren kehanetlere sahiptirler. Liderler, çalışanlardan yüksek beklentilere sahiplerse ancak o zaman yüksek verimliliğe ulaşabilirler. Bunun için de örgüt hedefleriyle kişisel hedefler birbirine uyumlu hale getirilmelidir. Liderler, iyi ilişkiler ve güçlendirme yoluyla bu iki tür hedefin çatışmasını engeller. Politik boyuta göre örgütler ormanlar gibidir. Sahip olunan kit kaynaklar nedeniyle insanlar birbirleriyle sürekli rekabet halindedirler. Bunun sonucunda çatışmalar ortaya çıabilmektedir. Politik oryantasyondaki liderler, çatışmaları çözümlemektense en baştan çıkmalarını engellemek için stratejik davranırlar. Bunun için de politik olmak ve güç ilişkilerini iyi dengelemek gerekir. Liderler pazarlık, zorlama ve manipülasyona başvurarak güç dağılımını sürekli düzenler, gerektiğinde koalisyonlar oluştururlar. Sembolik boyuta göre örgütler ibadethane veya tiyatrolar gibidir. Buralarda ritüel, mit, seremoni, hikâye, mizah, ilham, maskot, sembol ve metaforlarla anlam ve inanca vurgu yapılarak özgün bir kültür oluşturulur. Çalışanların aitlik ihtiyaçları karşılanır ve onlara takım ruhu aşılanır. Emirler yerine örneklerle takımlar bir arada tutulur. Çeşitlilik bir fırsat olarak görülür. Özel bir jargonla, çalışanlar arasında birlik ve bağllık sağlanır. Hikâyelerle ortak tarih kayıt altına alınır ve grup kimliği oluşturulur. Mizah ve oyunlarla tansiyon düşürülür ve yaratıcılık özendirilir. Sembolik oryantasyona sahip liderler enformel ilişkilere özen gösterir, ortak değerlere vurgu yaparak sorumluluk aşılar ve başarıyı kutlayarak motive ederler.

Aday öğretmenlerin yetiştirilmesi, MEB Aday Memurların Yetiştirilmesine İlişkin Yönetmeliğe göre düzenlenen bir yetiştirme programıla olur. Programda 1) temel eğitim, 2) hazırlayıc eğitim ve 3) uygulama eğitimi olmak üzere üç farklı eğitim bulunmaktadır. Temel eğitimde genel olarak tüm aday memurlara verilen devlet memurluğu ile ilgili konular yer almaktadır. Hazırlayıcı eğitim, aday öğretmenlerin ihtiyaç duyduğu mesleğe ilişkin kuramsal bilgileri içerirken uygulamalı eğitim ise aynı konuda uygulama yapılarak deneyim kazanılması için etkinlikleri içermektedir. Okul müdürleri, bu eğitimin sağlamasında birinci derecede sorumlu bir rehber rolünü üstlenmektedirler. Gevşek yapılı örgütler olan okullarda müdürler, yöneticiden çok lider olmalıdırlar. Dolayısıyla okul müdürlerinin aday öğretmenlere sağladığı rehberlikte müdürlerin sahip oldukları liderlik oryantasyonlarının etkili olabileceği öngörülebilir. Fakat alanyazında bu ilişkiyi araştıran bir çalışmaya ulaşılamamıştır. Böyle bir ilişki belirlenebilirse, aday öğretmenlik eğitiminin daha verimli olabilmesi için veriye dayalı önlemler alınabilir. Bu araştırmanın amacı okul müdürlerinin okullarında görev yapan aday öğretmenlere rehberlik edebilme düzeyiyle liderlik oryantasyonları arasındaki ilişkiyi belirlemektir. Bu temel amaca ulaşmak için araştırma sürecinde yanıt aranan sorular şunlardır:

1. Okul müdürlerinin okullarında görev yapan aday öğretmenlere rehberlik edebilme düzeyi nedir?

2. Okul müdürlerinin liderlik oryantasyonları ne düzeydedir?

3. Okul müdürlerinin aday öğretmenlere rehberlik edebilme düzeyleriyle liderlik oryantasyonları arasındaki ilişkinin düzeyi nedir?

4. Okul müdürlerinin aday öğretmenlere rehberlik edebilme ve liderlik oryantasyonları, cinsiyet, okul türü, branş ve görev yerine göre farklllık göstermekte midir?

\section{Yöntem}

\section{Model}

Araştırma ilişkisel tarama modeliyle gerçekleştirilmiştir. Araştırma sorularının doğası gereği elde edilecek sonuçları genelleme ihtiyacı hissedilmiş ve bu model tercih edilmiştir. Çünkü bu model ile evreni temsil eden bir örneklemin görüş ve algılarının taranması esas alınmaktadır. Örneklemin kalabalık olmasından dolayı 
nicel verilerin toplanması ve analiz edilmesi süreci mümkün kılmaktadır. Bu modelde asıl olan, incelenen değişkenler arasındaki ilişkileri veriye dayalı olarak ortaya koymaktır (Fraenkel, Wallen ve Hyun, 2012).

\section{Evren ve Örneklem}

Şanlıurfa'da 2019 bahar döneminde görev yapan 4857 aday öğretmenden 307 aday öğretmene kolaylı örneklemeyle ulaşılmıştır. Öğretmenlerin demografik verileri Tablo 1'de sunulmuştur.

Tablo I

Aday Öğretmenlerin Demografik Verileri

\begin{tabular}{lccc}
\hline \multirow{2}{*}{ Cinsiyet } & & Frekans & Yüzde \\
& Erkek & 84 & 27.4 \\
\cline { 2 - 4 } Okul Türü & Kadın & 223 & 72.6 \\
& İlkokul & 144 & 46.9 \\
\cline { 2 - 4 } & Ortaokul & 112 & 36.5 \\
\cline { 2 - 4 } Branş & Lise & 46 & 16.6 \\
& Sinıf & 100 & 32.6 \\
\hline \multirow{2}{*}{ Görev Yeri } & Branş & 207 & 67.4 \\
& Kasaba, köy vb. & 215 & 70.0 \\
\cline { 2 - 4 } & İlçe & 30 & 9.8 \\
\hline
\end{tabular}

Aday öğretmenlerin 84'ü erkek, 223'ü kadındır. Öğretmenlerin 144'ü ilkokulda, 112'si ortaokulda ve 46's1 lisede görev yapmaktadırlar. Sınıf öğretmenliği mezunu olan 100, branş öğretmenliği mezunu olan 207 aday öğretmen bulunmaktadır. Görev yeri bakımından 215 öğretmen kasaba, köy ve benzeri yerlerde, 30 öğretmen ilçede ve 62 öğretmen il merkezinde görev yaptığını belirtmiştir.

\section{Veri Toplama Araçları}

Aday öğretmenlerin demografik verileri cinsiyet, çalışılan okul türü, öğretmenlik branşı ve görev yeri büyüklüğü sorularıyla toplanmıştır. Aday öğretmenlerin iş başında yetiştirilmesinde okul müdürlerinin rolünü belirlemek için Ekinci (2010) tarafından geliştirilen Müdürlerin Aday Öğretmenlere Rehberlik Edebilme Düzeyi Ölçeği kullanılmıştır. Ölçekte 38 madde ve 3 alt boyut bulunmaktadır. Eğitim-öğretim alt boyutunda bulunan maddelerden biri "Planlarımı, çevre koşulları ve ders programlarına uygun olarak hazırlamamda bana rehberlik eder." şeklindedir. Okula ve çevreye uyum sağlama alt boyutuna "Okula ve mesleğe uyum sağlamamda yeterince destek olur." maddesi örnek verilebilir. İlgili mevzuat ve görevle ilgili sorumluluklar alt boyutunda "Özlük haklarım hakkında bilgiler verir." maddesi örnek gösterilebilir. Bu araştırmada toplanan verilere göre ölçeğe ait Cronbach alfa güvenirlik katsayısı $\alpha=0.97$ olarak hesaplanmıştır. Aday öğretmenlerin okul müdürlerinin liderlik oryantasyonlarını belirlemek için Bolman ve Deal (1991) tarafından geliştirilen, Thompson (2005) tarafından son hali verilen, Özcan ve Balyer (2013) tarafından Türkçeye uyarlanan Liderlik Oryantasyon Ölçeği kullanılmıştır. Ölçekte 32 madde ve 4 alt boyut bulunmaktadır. Yapısal çerçeve alt boyutu için "Kurumum açık ve anlaşılır bir yönetim yapısına sahiptir.", insan kaynakları çerçevesi için "Kurumum çalışanlarını destekler ve onlara ilgi gösterir.", politik çerçeve için "Kurumum kurumsal çatışmayı (rekabet) öngörür ve bunları başarıyla yönetir.", sembolik çerçeve için "Kurumum güçlü, bir vizyon ve misyon fikri oluşturur." maddeleri örnek verilebilir. Bu araştırmada toplanan verilere göre ölçeğe ait Cronbach alfa güvenirlik katsayısı $\alpha=0.96$ olarak hesaplanmıştır. Her iki ölçek de beşli Likert tipinde derecelendirilmiştir.

\section{Verilerin Toplanması ve Analizi}

Veri toplama araçları tek bir form haline getirilmiş ve aday öğretmenlerce yanıtlanmıştır. Veriler SPSS programına girilmiş ve analiz edilmiştir. Verilerin önce normal dağılımı incelenmiş ve sonuca göre analiz yöntemleri belirlenmiştir. Çarpıklık ve basıklık değerleri genellikle -1 ile +1 arasında olduğundan parametrik analizler tercih edilmiştir. İlk araştırma sorusu için alt boyutların ortalama ve standart sapmaları hesaplanmış, likert dereceleme aralıklarına göre yorumlanmıştır. Üçüncü araştırma sorusu için alt boyutlar arasında Pearson momentler çarpımı korelasyonu hesaplanmıştır. Dördüncü araştırma sorusu için bağımsız gruplar ttesti ve tek yönlü varyans analizi (ANOVA) kullanılmıştır. Farklılık kaynağı Tukey testi ile belirlenmiştir. 


\section{Bulgular}

Birinci ve ikinci araştırma sorularının yanıtlanması için veri toplama araçlarının alt boyutlarının ortalama ve standart sapmaları hesaplanmıştır. Bulgular çarpıklık ve basıklık değerleriyle birlikte Tablo 2'de sunulmuştur.

Tablo II

Rehberlik Etme Ve Liderlik Oryantasyonu Alt Boyutlarına İlişkin İstatistikler

\begin{tabular}{|c|c|c|c|c|}
\hline Alt Boyutlar & Ortalama & Std. Sapma & Çarpıklık & Basıklık \\
\hline Eğitim-Öğretim & 3.04 & 1.17 & -0.03 & -1.04 \\
\hline Okula ve Çevreye Uyum Sağlama & 3.34 & 1.16 & -0.36 & -0.88 \\
\hline İlgili Mevzuat ve Görevle İlgili Sorumluluklar & 3.18 & 1.13 & -0.16 & -0.89 \\
\hline Rehberlik Etme Toplamı & 3.19 & 1.11 & -0.17 & -0.94 \\
\hline Yapısal Çerçeve & 3.37 & 1.05 & -0.54 & -0.43 \\
\hline İnsan Kaynakları Çerçevesi & 3.41 & 1.13 & -0.49 & -0.60 \\
\hline Politik Çerçeve & 3.35 & 1.08 & -0.54 & -0.49 \\
\hline Sembolik Çerçeve & 3.22 & 1.11 & -0.32 & -0.79 \\
\hline Liderlik Oryantasyonu Toplamı & 3.34 & 1.04 & -0.49 & -0.47 \\
\hline
\end{tabular}

Tüm alt boyutların ortalamaları Likert dereceleme aralıklarına (Hiç: 1.00-1.79, Nadiren: 1.80-2.59, Bazen: 2.60-3.39, Sık sık: 3.40-4.19, Daima: 4.20-5.00) göre "bazen" sıklığına denk gelmektedir. Dolayısıyla okul müdürlerinin okullarında görev yapan aday öğretmenlere rehberlik edebilme ve liderlik oryantasyonlarının orta düzeyde olduğu söylenebilir.

Üçüncü araştırma sorusuna yanıt aramak için yapılan korelasyon analizi Tablo 3’de sunulmuştur.

Tablo III

Alt Boyutlar Arasindaki Korelasyonlar

\begin{tabular}{lcccccc}
\hline & OÇUS & IMGIS & YÇ & İKÇ & PÇ & SÇ \\
\hline EÖ & $0.89^{*}$ & $0.88^{*}$ & $0.71^{*}$ & $0.76^{*}$ & $0.73^{*}$ & $0.78^{*}$ \\
\hline OÇUS & & $0.89^{*}$ & $0.72^{*}$ & $0.80^{*}$ & $0.76^{*}$ & $0.77^{*}$ \\
\hline IMGIS & & $0.73^{*}$ & $0.76^{*}$ & $0.74^{*}$ & $0.77^{*}$ \\
\hline YÇ & & & & $0.87^{*}$ & $0.85^{*}$ & $0.83^{*}$ \\
\hline IKÇ & & & & & $0.87^{*}$ & $0.86^{*}$ \\
\hline PÇ & & & & & $0.90^{*}$ \\
\hline
\end{tabular}

${ }^{*} \mathrm{p}<0.001$

Tüm alt boyutlar arasında 0.70 'in üzerinde anlamlı $(\mathrm{p}<0.001)$ ilişkiler belirlenmiştir. Dolayısıyla okul müdürlerinin aday öğretmenlere rehberlik edebilme düzeyleriyle liderlik oryantasyonları arasında yüksek düzeyde bir ilişki olduğu söylenebilir.

Dördüncü araştırma sorusunu yanttlamak için okul müdürlerinin aday öğretmenlere rehberlik edebilme ve liderlik oryantasyonlarının demografik değişkenlere göre farklılıkları incelenmiştir. Belirlenen farklılıklar Tablo 4'de sunulmuştur.

Tablo IV

Okul Müdürlerinin Aday Öğretmenlere Ĕ̆itim-Öğretim Alt Boyutunda Rehberlik Edebilmelerinin Demografik Değişkenlere Göre Farklllkları

\begin{tabular}{|c|c|c|c|c|c|}
\hline & & Ortalama & Std. Sapma & $\mathrm{F} / \mathrm{T}$ & p \\
\hline \multirow{3}{*}{ Okul Türü } & İlkokul & 3.14 & 1.24 & \multirow{3}{*}{4.81} & \multirow{3}{*}{$0.01^{*}$} \\
\hline & Ortaokul & 2.78 & 1.14 & & \\
\hline & Lise & 3.33 & 0.94 & & \\
\hline \multirow{2}{*}{ Branş } & Sinif & 3.27 & 1.24 & \multirow{2}{*}{2.33} & \multirow{2}{*}{$0.02^{*}$} \\
\hline & Branş & 2.94 & 1.12 & & \\
\hline
\end{tabular}

Cinsiyete ( $\mathrm{t}_{305}=-0.133$; $\mathrm{p}>0.05$ )göre farklılıkları belirlemek için yapılan bağımsız gruplar $\mathrm{t}$-testine göre anlamlı bir farklılık belirlenmemiştir. Okul türüne göre farklılıkları belirlemek için yapılan ANOVA'ya göre sadece eğitim-öğretim alt boyutunda anlaml farklılık belirlenmiştir $\left(\mathrm{F}_{2-298}=4.81, \mathrm{p}<0.05\right)$. Ortaokulda görev yapan aday öğretmenlerin (Ort=2.78, ss=1.14), ilkokul (Ort=3.14, ss=1.24) ve lisede (Ort=3.33, ss=0.94) görev yapan aday öğretmenlerden daha olumsuz algılara sahip oldukları belirlenmiştir. Branşa göre farklılıkları 
belirlemek için yapılan bağımsız gruplar t-testine göre sadece eğitim-öğretim alt boyutunda anlamlı farklılık belirlenmiştir $\left(t_{(305)}=2.33, p<0.05\right)$. Sınıf öğretmenliği mezunu aday öğretmenler (Ort=3.27, ss=1.24) branş öğretmenliği mezunu aday öğretmenlerden $(\mathrm{Ort}=2.94, \mathrm{ss}=1.12)$ daha olumlu alg1lara sahiptirler. Görev yerine $\left(\mathrm{F}_{2-298}=0,26 ; \mathrm{p}>0.05\right)$ göre farklılıkları belirlemek için yapılan ANOVA'ya göre anlamlı bir farklılık belirlenmemiştir.

\section{Sonuç ve Tartışma}

Okul müdürlerinin okullarında görev yapan aday öğretmenlere rehberlik edebilme düzeyiyle liderlik oryantasyonları arasındaki ilişkiyi belirlemek için yapılan bu araştırmada şu sonuçlara ulaşılmıştır: 1) Okul müdürleri, okullarında görev yapan aday öğretmenlere orta düzeyde rehberlik etmektedirler, 2) Okul müdürlerinin liderlik oryantasyonları orta düzeydedir, 3) Okul müdürlerinin aday öğretmenlere rehberlik edebilme düzeyleriyle liderlik oryantasyonları arasında yüksek düzeyde ilişki bulunmaktadır, 4) İlkokul ve lise müdürleri, ortaokul müdürlerine göre aday öğretmenlere eğitim-öğretim alt boyutunda daha iyi rehberlik etmekte; okul müdürleri, sınıf öğretmenliği mezunu aday öğretmenlere branş öğretmenliği mezunu aday öğretmenlerden daha iyi rehberlik etmekte ve liderlik oryantasyonları cinsiyet, okul türü, branş ve görev yerine göre farklılık göstermemektedir.

$\mathrm{Bu}$ araştırmada elde edilen ilk sonuca göre okul müdürleri, okullarında görev yapan aday öğretmenlere orta düzeyde rehberlik etmektedirler. Müdürlerce aday öğretmenlere sağlanan rehberliğin önemi düşünüldügünde, bu düzeyin yetersiz olduğu söylenebilir. Bu durum önceki araştırma sonuçlarıyla da tutarlıdır (Ekinci, 2010; İlyas, Coşkun ve Toklucu, 2017). Ayrıca alt boyutların ortalamalarına göre en düşük rehberlik eğitim-öğretim alanında sağlanmıştır. Nitekim Ekinci (2010) de benzer bir sonuçla karşılaşmıştır. Yılmaz (2017) araştırmasının sonucunda aday öğretmenlere rehberlik amacıyla alanında yeterli olan kişilerin eğitim vermediğini belirlemiştir. Dolayısıyla aday öğretmenlerin aldıkları rehberliği yeterli bulmamalarının nedeni okul müdürlerinin bu konuda yetersiz olmaları olabilir. İlyas, Coşkun ve Toklucu (2017) da okul yöneticilerinin adaylık eğitimine yeterince olumlu yaklaşmadıklarını belirlemişler ve bunun nedeni olarak ilk defa uygulanan bu sürecin yöneticilere ek külfet getirmesini öne sürmüşlerdir. Bu nedenle de okul müdürlerinin adaylık sürecine ilişkin yaklaşımları ve süreç boyunca artan iş yükleri müdürlerin rehberliğini olumsuz etkilemiş olabilir. Konuyla ilgili önceki araştırmaların sonuçları adaylık sürecinin olumlu ve olumsuz yönlerini ortaya koymaktadır. Bu sonuçlarda müdürlerin rehberliği üzerinde rol oynayabilir. Örneğin; Gül, Türkmen ve Aksel (2017), aday öğretmenlerin danışman öğretmenlerinden oldukça yararlandıklarını fakat sürecin uygulanmasında bazı aksaklıkların yaşandığını ifade ettiklerini bildirmişlerdir. Köse (2016), aday öğretmenlerin danışman öğretmenleriyle derse girmelerinin ve usta-çırak ilişkisinin olumlu sonuçlandığını belirtmiştir. Sarikaya, Samancı ve Yılar (2017, s. 939), aday öğretmen eğitim sürecinin “özgüven sağlama, sınıf yönetimi, planlama, materyal tasarlama, müfredat, iletişim ve etkileşim boyutlarında adaylara gelişme imkânı" sunduğunu fakat "adayların dışlanması, öğretmen muamelesi görmemesi, toplantılara alınmaması, boş derslere görevlendirilmesi ve tek bir sinıfta gözlem yapma mecburiyetinde bırakılması" gibi sorunların yaşandığını belirtmişlerdir. Kozikoğlu ve Soyalp (2018, s. 934), sürecin "aday öğretmenlere deneyim kazandırarak onları mesleğe hazırlama, idari iş ve işlemleri, okul içi işleyişi öğrenmelerini sağlama, öğrenciler, veliler ve okuldaki diğer personelle nasıl iletişim kuracaklarını bilmelerini sağlama, ildeki ilgili kurumları tanıma, kurumların işleyişi hakkında bilgi sahibi olma ve dolayısıyla ihtiyaç duyduklarında hangi kuruma başvurmaları gerektiğini bilme gibi olumlu yönlerinin" olduğunu fakat "doldurulması gereken rapor/formların fazla olması, aday öğretmenlerin, danışman öğretmenlerin ve okul yöneticilerinin program hakkında yeterince bilgilendirilmemesi" gibi olumsuzlukların bulunduğunu belirlemişlerdir. Nayır ve Çetin (2017), aday öğretmenlerin mentörlük uygulamasını yararlı bulduklarını bildirmişlerdir. Ulubey (2017, s. 1), "sınıf içi gözlemlerin, okul içi ve okul dışı uygulamaların, önerilen film ve kitapların mesleğe uyum sağlamada yararlı olduğu, mesleki bilgi ve becerileri geliştirdiği, öğrencilere, sınıfa ve okula uyuma katkı sağladığını" fakat paydaşların süreci tam olarak anlayamadıkları için sorunların yaşandığını belirtmiştir. Köse ve Atalmış (2017, s. 491), aday öğretmen rehberlik sürecinin "sınıf yönetimi, öğretim ilke ve yöntemleri, ölçme ve değerlendirme ve öğrenci-öğretmen ilişkileri" bakımından yararlı olduğunu fakat aday öğretmenlerin eğitimlerin süresini uzun bulduklarını belirlemişlerdir. Tüm bu sonuçlar aday öğretmenlerin sürece ilişkin 
algılarını şekillendirmiş olabilir.

Araştırmanın ikinci sonucuna göre aday öğretmenler, okul müdürlerinin liderlik oryantasyonlarını orta düzeyde algılamışlardır. Dolayısıyla müdürlerin liderlik oryantasyonlarının yeterli düzeyde olmadığı ileri sürülebilir. Okul müdürleriyle yapılan bir araştırmada ise müdürler, liderlik oryantasyonlarını daha yüksek düzeyde algılamışlardır (Özdemir, 2018). Bu farklılığın kaynağı müdürlerin kendilerini daha olumlu algılamış olabilecekleridir. Bu araştırmaya göre en çok kullanılan liderlik oryantasyonları insan kaynakları ve yapısal çerçeve boyutlarındadır. Önceki bir araştırmada da müdürlerin en çok yapısal çerçeve boyutunda oldukları belirlenmiştir (Özdemir ve Koçak, 2018). Yapısal çerçevenin daha çok yöneticiliğe benzer özelliklere sahip olması, bu durumda rol oynamış olabilir. Fakat liderlik oryantasyonlarının düzeyleri arasında çok fazla farklılık bulunmamaktadır. Bu nedenle müdürlerin tüm çerçevelerde etkin olmaya çalıştıkları ama yeterli düzeylere ulaşamadıkları söylenebilir. Alanyazında liderlik oryantasyonlarına ilişkin az sayıda araştırmaya ulaşılabildiğinden bu sonuca neden olabilecek etkenlerin belirlenmesi önemli görülebilir.

Araştırmada elde edilen diğer bir sonuç da okul müdürlerinin aday öğretmenlere rehberlik edebilme düzeyleriyle liderlik oryantasyonları arasında yüksek düzeyde anlamlı ilişkilerin bulunduğudur. Rehberlik, doğası gereği, yöneticiliktense liderliği gerektirmiş olabilir. Çünkü rehberler usta-çırak ilişkilerine benzer bir şekilde öğretmenlere yakın davranmalıdırlar. Bu ise yönetimin hiyerarşiden kaynaklanan güç kullanımını engelleyebilir. Rehberlikte liderliğe benzer şekilde ikna ve güdüleme esas alınmalıdır. Böylece liderlik sergileyen müdürlerin yöneticiliği öne çıaran müdürlerden daha etkin bir şekilde rehberlik etmeleri mümkün olabilir. Bu da rehberlik düzeyleriyle liderlik oryantasyonları arasındaki ilişkinin nedeni olabilir.

Araştırmada elde edilen dördüncü sonuca göre ilkokul ve lise müdürleri ortaokul müdürlerine göre aday öğretmenlere eğitim-öğretim alt boyutunda daha iyi rehberlik etmekte, okul müdürleri sınıf öğretmenliği mezunu aday öğretmenlere branş öğretmenliği mezunu aday öğretmenlerden daha iyi rehberlik etmekte ve liderlik oryantasyonları cinsiyet, okul türü, branş ve görev yerine göre farklılık göstermemektedir. Benzer farklılıklar alanyazında da belirtilmiştir. Örneğin; Ekinci (2010), aday öğretmenlerin görüşlerine göre ilköğretim okulu müdürlerinin ortaöğretim okulu müdürlerinden, sınıf öğretmeni olan okul müdürlerinin branş öğretmeni okul müdürlerinden daha yüksek düzeyde mesleki rehberlikte bulunduklarını belirlemiştir. Tunçbilek ve Tünay (2017) ise kıdem, cinsiyet, branş ve yaşa göre aday öğretmen yetiştirme sürecinde farklılık belirlememiştir. Balyer ve Özcan (2017), 12 yıldan fazla deneyimi olan öğretmenlerin sembolik çerçeveyi daha yüksek düzeyde algıladıklarını belirlemişlerdir. Okul müdürlerine rehberlik sürecine ilişkin eğitimlerin verilmediği düşünüldüğünde tüm bu farklılıkların eğitim eksikliğinden etkilenmiş olabileceği öngörülebilir. Okul müdürlerinin rehberliğe ilişkin eğitim almaları, müdürlerin kişisel özelliklerinden bağımsız bir şekilde rehberlik etmelerini sağlayabilir.

\section{Öneriler}

Araştırmanın sonuçlarına ve tartışılan olası nedenlere göre bazı öneriler verilebilir. Okul müdürleri aday öğretmen rehberlik sürecine ilişkin eğitilmelidirler. Okul müdürlerinin liderlik oryantasyonlarının ve rehberliklerinin yeterli olmamasının nedenleri araştırılmalı ve önlemler alınmalıdır. Okul müdürlerinin aday öğretmenlere etkin bir şekilde rehberlik etmeleri için müdürlerin daha fazla liderlik sergilemelerini sağlayabilecek düzenlemeler yapılmalıdır.

\section{Kaynaklar}

Aday Öğretmen Yetiştirme Sürecine Dair Yönerge (2016, Mart). Tebliğler Dergisi (Sayı: 2702). Erişim adresi: http://tebligler.meb.gov.tr/index.php/tuem-sayilar/viewcategory/84-2016

Akdağ, Z. (2014). Beginning early childhood education teachers' struggles in remote areas. International Journal of Educational Researchers, 5(3), 1-13.

Arslan, S. ve Özpınar, İ. (2008). Öğretmen nitelikleri: İlköğretim programlarının beklentileri ve eğitim fakültelerinin kazandırdıkları. Necatibey Ĕ̆itim Fakültesi Elektronik Fen ve Matematik Eğitimi Dergisi, 2(1), 38-63. 
Balkar, B. ve Şahin, S. (2014). The opinions of educators on implementing mentorship program for novice teachers. The Journal of Academic Social Science Studies International Journal of Social Science, 3(29), 83-100.

Balyer, A. ve Özcan, K. (2017). İlköğretim okullarında örgütsel iklim ve bu iklimin öğretmenlerin iş doyumları üzerindeki etkileri. Kastamonu Ĕ̆itim Dergisi, 25(5), 1737-1752.

Bolman, L. G. ve Deal, T. E. (1991). Leadership and management effectiveness: A multi-frame, multi-sector analysis. Human Resource Management, 30(4), 509-534.

Bolman, L. G.ve Deal, T. E. (2017). Reframing organizations: Artistry, choice, and leadership (6. bs.). Hoboken, NJ: Jossey-Bass.

Devlet Memurları Kanunu (1965, Temmuz). Resmî Gazete (Sayı: 12056). Erişim adresi: https://www.mevzuat.gov.tr/MevzuatMetin/1.5.657.pdf

Duran, E., Sezgin, F. ve Çoban, O. (2011). Aday sınıf öğretmenlerinin uyum ve sosyalleşme sürecinin incelenmesi. Dumlupınar Üniversitesi Sosyal Bilimler Dergisi, 31, 465-478.

Ekinci. A. (2010). Aday öğretmenlerin iş başında yetiştirilmesinde okul müdürlerinin rolü. Dicle Üniversitesi Ziya Gökalp Ĕ̆itim Fakültesi Dergisi, 15, 63-77.

Erdemir, N. (2007). Mesleğine yeni başlayan fen bilgisi öğretmenlerinin karşılaştıkları sorunlar ve şikâyetler. Elektronik Sosyal Bilimler Dergisi, 6(22), 135-149.

Feiman-Nemser, S. (2003). What new teachers need to learn. Educational Leadership, 60(8), 25-29.

Fraenkel, J. R., Wallen, N. E. ve Hyun, H. H. (2012). How to design and evaluate research in education (8. bs.). New York: McGraw-Hill.

Gül, İ., Türkmen, F. ve Aksel, N. (2017). Aday öğretmen görüşlerine göre aday öğretmen yetiştirme sürecinin değerlendirilmesi. Hitit Üniversitesi Sosyal Bilimler Enstitüsü Dergisi, 10(1), 365-388.

Hammond, M. (2005). Next steps in teaching: A guide to starting your career in the secondary school. London: Routledge.

Hususi İdarelerden Maaş Alan İlkokul Öğretmenlerinin Kadrolarına, Terfi, Taltif ve Cezalandırılmalarına ve Bu Öğretmenler İçin Teşkil Edilecek Sağlık ve İçtimai Yardım Sandığı ile Yapı Sandığına ve Öğretmenlerin Alacaklarına Dair Kanun (1943). Resmî Gazete (Sayı: 5308). Erişim adresi: https://mevzuat.tbmm.gov.tr/mevzuat/faces/kanunmaddeleri?pkanunlarno=41547\&pkanunnumarasi=43 57

İlk ve Orta Tedrisat Muallimlerinin Terfi ve Tecziyeleri Hakkında Kanun. (1930, 10 Haziran). Resmî Gazete (Sayı: 1532). Erişim adresi: http://www.mevzuat.gov.tr/MevzuatMetin/5.3.1702.pdf.

İlyas, İ. E., Coşkun, İ. ve Toklucu, D. (2017). Türkiye'de aday öğretmen yetiştirme modeli: İzleme ve değerlendirme. Ankara: SETA Yayınları.

Korkmaz, İ., Saban, A. ve Akbaşlı, S. (2004). Göreve yeni başlayan sınıf öğretmenlerinin karşılaştıkları güçlükler. Kuram ve Uygulamada Ĕ̆itim Yönetimi Dergisi, 38(38), 266-277.

Kozikoğlu, İ. ve Çökük, K. (2017). Aday öğretmenlerin adaylık eğitimini atandıkları ilden farklı bir ilde tamamlamaları: Aday öğretmenlerin görüş ve deneyimleri. Ankara Üniversitesi Eğitim Bilimleri Fakültesi Dergisi, 50(2), 167-200.

Kozikoğlu, İ. ve Senemoğlu, N. (2018). Mesleğe yeni başlayan öğretmenlerin karşılaştıkları güçlükler: Nitel bir çözümleme. Ĕ̆itimde Nitel Araştırmalar Dergisi, 6(3), 341-371.

Kozikoğlu, İ. ve Soyalp, H. (2018). Aday öğretmenlerin, danışman öğretmenlerin ve okul yöneticilerinin aday öğretmen yetiştirme programına yönelik görüşlerinin incelenmesi. Hacettepe Üniversitesi Eğitim Fakültesi Dergisi, 33(4), 934-952. 
Köse, A. (2016). Okul yöneticilerinin görüşlerine göre aday öğretmen yetiştirme sürecinin değerlendirilmesi. Abant İzzet Baysal Üniversitesi Ĕ̆itim Fakültesi Dergisi, 16(3), 924-944.

Köse, A. ve Atalmış, E. H. (2017). Aday öğretmen yetiştirme sürecinde alınan eğitimlerin öğretmenlik uygulamalarına katkısı: Sorunlar ve çözüm önerileri. Turkish Studies, 12(25), 491-512.

Millı̂ Eğitim Bakanlığı Aday Memurların Yetiştirilmelerine İlişkin Yönetmelik (1995, Ocak). Tebliğler Dergisi (Sayı: 2423). Erişim adresi: http://tebligler.meb.gov.tr/index.php/tuem-sayilar/viewcategory/59-1995

Milli Eğitim Gençlik ve Spor Bakanlığına Bağlı Okul ve Kurumlara Stajyer Olarak Atanan Öğretmenlerin Stajyerlik İşlemlerine İlişkin Yönerge (1985, Nisan). Tebliğler Dergisi (Sayı: 2186). Erişim adresi: http://tebligler.meb.gov.tr/index.php/tuem-sayilar/viewcategory/49-1985

Nayır, F. ve Çetin, S. K. (2017). Aday öğretmenlerin danışman öğretmenlik uygulamasına ilişkin görüşleri (Muğla ili örneği). Journal of Education and Future, 12, 137-155.

Öğretmen Atama ve Yer Değiştirme Yönetmeliği (2015, Nisan). Resmî Gazete (Sayı: 29329). Erişim adresi: http://www.resmigazete.gov.tr/eskiler/2015/04/20150417-4.htm

Özcan, K. ve Balyer, A. (2013). Liderlik oryantasyon ölçeğinin Türkçeye uyarlanması. Mersin Üniversitesi Eğitim Fakültesi Dergisi, 9(1), 136-150.

Özdemir, M. (2018). Liderlik yönelimi ve politik beceri arasındaki ilişkinin okul müdürlerinin görüşlerine göre incelenmesi. Ege Ĕ̆gitim Dergisi, 19(1), 116-134.

Özdemir, M. ve Koçak, S. (2018). Predicting teacher emotional labour based on multi-frame leadership orientations: A case from Turkey. Irish Educational Studies, 37(1), 69-87.

Özonay, İ. Z. (2004, Temmuz). Öğretmenlerin adaylık eğitimi programının değerlendirmesi. XIII. Ulusal Eğitim Bilimleri Kurultayı, Malatya.

Sarı, M. H. ve Altun, Y. (2015). Göreve yeni başlayan sınıf öğretmenlerinin karşılaştıkları sorunlar. Hacettepe Üniversitesi Ĕ̆itim Fakültesi Dergisi, 30(1), 213-226.

Sarikaya, İ., Samancı, Ö. ve Yılar, Ö. (2017). Aday öğretmen yetiştirme sürecinin aday ve danışman sınıf öğretmenlerinin görüşleri kapsamında değerlendirilmesi: Bir karma yöntem çalışması. Gazi Üniversitesi Gazi Ĕ̆itim Fakültesi Dergisi, 37(3), 939-989.

Smith, T. M. ve Ingersoll, R. M. (2004). What are the effects of induction and mentoring on beginning teacher turnover? American Educational Research Journal, 41(3), 681-714.

Thompson, M. D. (2005). Organizational climate perception and job element satisfaction: A multi-frame application in a higher education setting. E-Journal of Organizational Learning and Leadership, 4(1), 1-15.

Topsakal, C. ve Duysak, A. (2017). Aday öğretmen yetiştirme sürecine ilişkin aday öğretmenler ve diğer paydaşların görüşleri. Sakarya University Journal of Education, 7(3), 625-639.

Tunçbilek, M. ve Tünay, T. (2017). MEB aday öğretmen yetiştirme süreci uygulamasının ilgili tarafların bakış açısıyla değerlendirilmesi. Elektronik Sosyal Bilimler Dergisi, 16(61), 412-427.

Ulubey, Ö. (2017). Aday öğretmen yetiştirme programının değerlendirilmesi. Hacettepe Üniversitesi Ĕ̆gitim Fakültesi Dergisi, 33(2), 480-502.

Wong, J. L. ve Tsu, A. B. (2007). How do teachers view the effects of school-based in-service learning activities? A case study in China. Journal of Education for Teaching, 33(4), 457-470.

Yılmaz, M. (2017). Aday öğretmen yetiştirme sürecinde karşılaşılan sorunlar ve çözüm önerileri. 21. Yüzyılda Eğitim ve Toplum, 6(16), 135-156.

Yirci, R. ve Kocabaş, İ. (2010). The importance of mentoring for school principals: A conceptual analysis. International Journal of Educational Leadership Preparation, 2(5), 1-7. 


\section{EXTENDED ABSTRACT}

\section{Introduction}

It can be foreseen that the principals' leadership orientation can be effective in the guidance provided by the school principals. However, a study investigating this relationship could not be reached in the literature. If such a relationship can be identified, data-based measures can be taken to make prospective teacher training more efficient. The aim of this study was to determine the relationship between the level of being able to guide primary school teachers and their leadership orientation. In order to reach this basic goal, the following questions are answered: 1 . What is school principals' the level of being able to guide prospective teachers in their schools? 2. What are the leadership orientations of school principals? 3. What is the level of relationship between school principals' levels of guidance to prospective teachers and leadership orientations? 4. Are school principals differing in terms of being able to guide prospective teachers and leadership orientations, according to gender, type of school, branch, and task location?

\section{Method}

The research was conducted with correlational survey model. The need to generalize the results to be obtained by the nature of the research questions was felt and this model was preferred. Because this model is based on surveying the views and perceptions of a sample representing the population. Due to the crowded sample, the process of collecting and analyzing quantitative data makes it possible. The main thing in this model is to reveal the relationships between the variables examined. 307 prospective teachers from 4857 prospective teachers working in spring 2019 in Şanlıurfa were reached. The demographic data of the prospective teachers were collected through questions of gender, type of school study, type of teaching and task location. The scale developed by Ekinci (2010) was used to determine the role of school principals in the training of prospective teachers on the job. There are 38 items and 3 sub-dimensions in the scale. According to the data collected in this study, Cronbach's alpha reliability coefficients for education-teaching, adaptation to school and environment, related legislation and duty-related responsibilities were calculated as $\alpha=0.97$. In order to determine the leadership orientation of the school principals, the scale developed by Bolman and Deal (1991) and adapted by Thompson (2005) and adapted to Turkish by Özcan and Balyer (2013) was used. There are 32 items and 4 sub-dimensions in the scale. According to the data collected in this study, the Cronbach alpha reliability coefficients for the structural framework, human resources framework, political framework, and symbolic framework sub-dimensions were calculated as $\alpha=0.96$. Both scales were rated in five-point Likert type. Data collection tools were formed into a single form and answered by prospective teachers. The data were entered into the SPSS program and analyzed. The normal distribution of the data was analyzed, and the analysis methods were determined according to the results. Since the skewness and kurtosis values were generally between -1 and +1 , parametric analyzes were preferred. For the first research question, mean and standard deviations of the sub-dimensions were calculated and interpreted according to the Likert grading intervals. For the third research question, Pearson moment product correlation was calculated. For the fourth research question, independent groups t-test and one-way analysis of variance (ANOVA) were used. The difference source was determined by the Tukey test.

\section{Results}

The results of this study, which was conducted to determine the relationship between the level of guidance of the school principals and their leadership orientations, were as follows: 1 . School principals provide medium-level guidance to prospective teachers working in their schools. 2. Leadership orientation of school principals is moderate. 3 . There is a high level of relationship between school principals' levels of being able to guide prospective teachers and leadership orientations. 4. Primary school and high school principals better guide than the secondary school principals in the education and teaching sub-dimension, and the school principals better guide the prospective teachers who have graduated from the department of primary school education than other prospective teachers and the orientations do not differ based on gender, type of school, branch and task location. 


\section{Conclusion}

Some suggestions may be given according to the results of the research and possible reasons discussed. School principals should be trained on the prospective teacher guidance process. School principals' leadership orientations and guidance should be investigated, and the precautions should be taken. Arrangements should be made to enable principals to show more leadership for the school principals to guide them effectively. 